
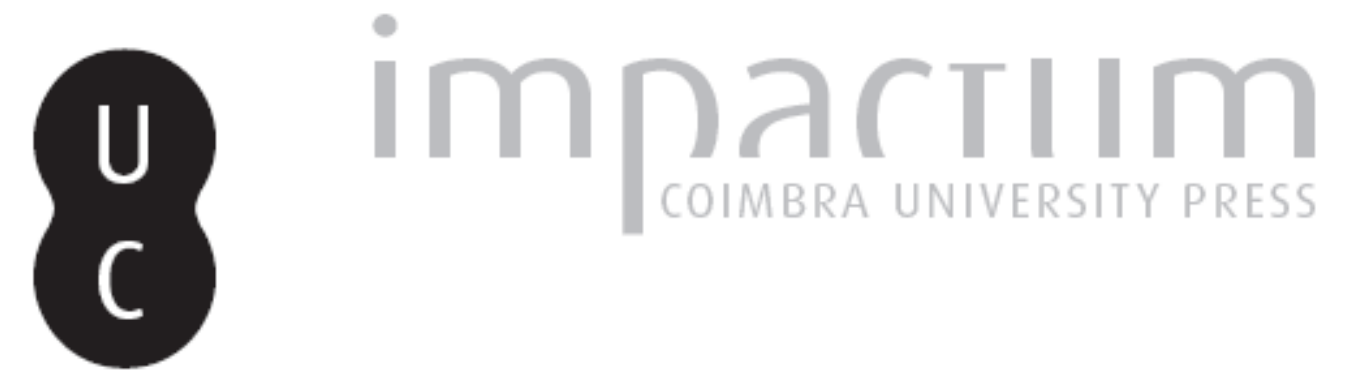

\title{
Gender wage differentials and occupational distribution
}

Autor(es): $\quad$ Mendes, Raquel Vale

Publicado por: Faculdade de Economia da Universidade de Coimbra

URL persistente:

URI:http://hdl.handle.net/10316.2/25210

DOI:

DOI:http://dx.doi.org/10.14195/2183-203X_29_2

Accessed : $\quad$ 26-Apr-2023 11:57:51

A navegação consulta e descarregamento dos títulos inseridos nas Bibliotecas Digitais UC Digitalis, UC Pombalina e UC Impactum, pressupõem a aceitação plena e sem reservas dos Termos e Condições de Uso destas Bibliotecas Digitais, disponíveis em https://digitalis.uc.pt/pt-pt/termos.

Conforme exposto nos referidos Termos e Condições de Uso, o descarregamento de títulos de acesso restrito requer uma licença válida de autorização devendo o utilizador aceder ao(s) documento(s) a partir de um endereço de IP da instituição detentora da supramencionada licença.

Ao utilizador é apenas permitido o descarregamento para uso pessoal, pelo que o emprego do(s) título(s) descarregado(s) para outro fim, designadamente comercial, carece de autorização do respetivo autor ou editor da obra.

Na medida em que todas as obras da UC Digitalis se encontram protegidas pelo Código do Direito de Autor e Direitos Conexos e demais legislação aplicável, toda a cópia, parcial ou total, deste documento, nos casos em que é legalmente admitida, deverá conter ou fazer-se acompanhar por este aviso.

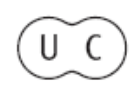




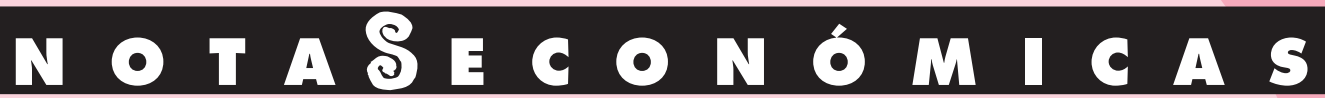

ANA BELA NUNES TOMÁS CABREIRA: UM ECONOMISTA POLIITICO NUM PAÍS DE "FINANÇAS AVARIADAS"

\begin{abstract}
RAQUEL VALE MENDES GENDER WAGE DIFFERENTIALS AND OCCUPATIONAL DISTRIBUTION
\end{abstract}
RITA MARTINS /

CARLOTA QUINTAL / ANA PIMENTEL
EQUIDADE: A CHAVE PARA EXPLICAR OS TARIFÁRIOS DE ÁGUA EM PORTUGAL

DOUTORAMENTO HONORIS CAUSA DO EMBAIXADOR JUAN SOMAVIA, DIRECTOR DA OIT 


\section{Gender wage differentials and occupational distribution}

Raquel Vale Mendes* Escola Superior de Gestão/Instituto Politécnico do Cávado e do Ave

resumo

résumé / abstract

O estudo analisa o papel da distribuição ocupacional dos trabalhadores na explicação das disparidades salariais entre homens e mulheres na economia portuguesa. $\mathbf{O}$ objectivo é de investigar até que ponto a desigualdade salarial entre homens e mulheres pode ser explicada pela segregação ocupacional. Com base em dados dos Quadros de Pessoal, o estudo aplica a metodologia de decomposição salarial de Brown, Moon e Zoloth (1980) ao período compreendido entre 1986 e 2004. Os principais resultados revelam que a distribuição ocupacional dos trabalhadores não contribui de forma significativa para a desigualdade salarial entre sexos e que as diferenças salariais intra-ocupacionais desempenham um papel fundamental na determinação do gap total.

Adicionalmente, os resultados indicam que uma parte substancial das disparidades salariais intra-ocupacionais deriva potencialmente da discriminação salarial.

\footnotetext{
* Mestre em Estudos Económicos e Sociais, Doutoranda em Ciências Económicas.
}

Acknowledgements: I am grateful to the Portuguese Ministry of Labor and Social Solidarity for the access to the data set used in this paper.

The access to the data was provided by the protocol signed between the Ministry and the Universidade do Minho.
L'étude analyse le rôle de la distribution occupationnelle des travailleurs pour expliquer les disparités des salaires entre hommes et femmes dans l'économie portugaise. L'objectif est de savoir jusqu'à quel point l'inégalité des salaires entre hommes et femmes peut être expliquée par la ségrégation occupationnelle. Pour arriver à une analyse empirique, sur la base des données des tableaux des effectifs, l'étude applique la méthodologie de la décomposition des salaires de Brown, Moon et Zoloth (1980) pour la période comprise entre 1986 et 2004. Les principaux résultats révèlent que la distribution occupationnelle des travailleurs ne contribue pas de forme significative à l'écart des salaires entre les sexes et que les différences de salaires intra occupationnelles jouent un rôle fondamental dans la détermination du différentiel. En outre, les résultats indiquent qu'une partie substantielle des disparités des salaires intra occupationnelles découle de la discrimination des salaires.

The study analyzes the role of occupational distribution in explaining the male-female wage gap in the Portuguese economy. The objective is to investigate to what extent gender wage disparities can be explained by occupational segregation. Relying on data from the personnel records for the period 1986-2004, this study uses the Brown, Moon, and Zoloth (1989) wage differential decomposition method to conduct the empirical analysis. The main findings reveal that occupational gender segregation is not a major contributor to the male-female wage gap and that within occupational wage effects play a prominent role in determining the overall differential. Additionally, the results indicate that a substantial portion of wage differentials within occupations potentially stems from wage discrimination.

Classificação JEL: J16, J31, J71. 


\section{Introduction}

Over the last decades, the Portuguese labor market has been marked by some dramatic changes. Perhaps the most striking aspect of these transformations has been the sharp increase of female participation in the labor force, enabling women to use their potential in the labor market and to achieve economic and financial independence. The increase has been such that the Portuguese female activity rate ranks among the highest of the European Union.

Why do women earn lower wages than men? The traditional approach in analyzing the determinants of the gender wage gap is to consider both the effects of gender differences in employees' human capital endowments and labor market discrimination. Recently, scholars focus on the role of gender segregation across occupations in explaining differences in earnings.

This paper studies the effect of occupational segregation on gender wage differentials in Portugal. Based on a nineteen year period (1986-2004), this paper aims at investigating if the wage gap has occurred mostly within occupations, or has the distribution of males and females across occupations played a prominent role in shaping the disparities. Hence, the main objective is to determine to what extent gender wage disparities can be explained by differences in the occupational distribution of male and female employees. Empirical results on the decomposition of the wage gap may be considered an important tool in defining policy measures aimed at promoting labor market equality on a gender basis.

Relying on micro data from the Quadros de Pessoal (Personnel Records), an extensive data set provided by the Portuguese Ministry of Labor and Social Solidarity, the Brown et al. (1980) wage differential decomposition method is used to conduct the empirical analysis. This method incorporates the distinction between within occupation (intra-occupational) and across occupation (inter-occupational) wage differentials. The main idea is to measure how much of the gap is explained by gender differences in wages within occupations and how much is explained by occupational gender segregation. This distinction is important as it may shed light on whether policies aimed at reducing the gender wage gap should focus more on promoting equality in pay within occupations or on redistributing labor across occupations.

Various empirical studies have applied the Brown et al. (1980) method, providing estimates of within occupation and across occupation wage disparities in different economies (e.g., Dolton and Kidd, 1994; Kidd, 1993; Kidd and Shannon, 1994; Meng and Miller, 1995; Plasman and Sissoko, 2004; Reilly, 1991). In the Portuguese case, there is no known study that attempts to measure the contribution of intra-occupational and inter-occupational effects to the observed gender wage gap.

This paper is organized as follows. Section 2 briefly reviews the theoretical explanations of the gender wage gap. Sections 3 and section 4 describe, respectively, the empirical model and the data set used, while section 5 presents and discusses the results. Concluding remarks are presented in section 6 .

\section{Sources of the gender wage gap}

The traditional approach in analyzing the determinants of the wage gap is to consider both the role of gender differences in human capital endowments and labor market discrimination ${ }^{1}$. The

1 Blau and Kahn (1996) additionally consider the role of wage structure in determining the magnitude of the gender wage gap. Defined as "the array of prices set for various labour market skills (measured and unmeasured) and rents received for employment in particular sectors of the economy" (Blau and Kahn, 1996: 29), wage structure determines the wage penalty or reward related to an individual's position in the wage distribution. For example, if female employees have less formal education than their male colleagues, the 
human capital theory (Mincer and Polachek, 1974) posits that the earnings of individual workers are a function of their past investment in human capital. The theory suggests that the gap can be explained by the fact that, when compared to men, women have fewer qualifications, such as formal education, labor market experience, and on-the-job training. The results of these differences in human capital are lower levels of productivity for women and, therefore, lower wages. This theory's explanation for gender differences in acquisitions of human capital is based upon the traditional role of women within the family. Because they tend to have shorter and more interrupted working lives than men, women invest less in labor market qualifications (Blau and Kahn, 1999).

In addition to differences in human capital endowments, labor market discrimination is often pointed out as a main source of gender wage differentials. Blau and Ferber (1986: 229) consider that labor market discrimination exists when "two equally qualified individuals are treated differently solely on the basis of their sex". Thus, in accordance with the labor market discrimination theory, gender disparities in earnings arise from the unequal treatment of equally productive males and females ${ }^{2}$. The two main theories of labor market discrimination are those referred to as theories of taste discrimination and theories of statistical discrimination (Stenzel, 2001). In Becker's (1957) model of taste discrimination, the unequal treatment of two groups arises from discriminatory tastes or personal prejudices against members of one of the groups. In models of statistical discrimination (e.g., Aigner and Cain, 1977), employers discriminate based on the average differences between two groups in the expected value of productivity or in the reliability with which this value can be predicted (Blau and Kahn, 1999).

More recently, scholars focus on the role of occupational gender segregation in explaining the gender wage gap. This type of segregation exists when men and women are employed in different types of occupations (Preston, 1999). The segregation theory suggests that gender differences in pay stem from the fact that female-dominated occupations are generally paid more poorly than those dominated by males (Boraas and Rodgers, 2003). To explain occupational segregation, Terrell (1992) distinguishes between labor supply and labor demand factors. On the labor supply side, the human capital approach views occupational distribution as a function of occupational choice. Given their traditional role within the family, women tend to invest less in human capital than men and select occupations on the basis of this role and these investments. On the labor demand side, occupational segregation is explained by employers' discrimination of women in their hiring practices in certain occupations (employment discrimination).

It is important to note that most economists do not necessarily consider mutually exclusive sources of the gender wage gap. Many authors refer to the possibility of more than one factor contributing to the determination of the gap. In her analysis of Portuguese female labor force participation, Cardoso (1996) concludes that gender wage differentials do not result exclusively from lower levels of female human capital and from the concentration of female employment in less regarded occupations or economic sectors. This author considers that disparities between male and female wages are also due to the fact that, at each human capital level and in each occupation or economic sector, women with equal characteristics as that of men are paid less.

greater the return to formal education (regardless of gender), the larger the size of the wage gap. As another example, if males and females are distributed differently across occupations, the higher the premium received by workers employed in male-dominated occupations (regardless of gender), the larger the wage gap.

2 Dex and Sloane (1988) distinguish two forms of labor market discrimination: wage discrimination and employment discrimination. Wage discrimination occurs when individuals with the same levels of productivity are paid different amounts, whereas employment discrimination occurs when individuals with the same levels of productivity are employed differently across occupations. These authors note that employment discrimination may or may not accompany wage discrimination. 


\section{The model}

Related to the theoretical discussion of the determinants of the gender wage gap is the fosmulation of mathematical and statistical methods aimed at decomposing wage differentials. These methods have become a popular and useful way to identify the sources of the wage gap and their contributions.

One of the most widely used decomposition methods is the traditional approach derived by Oaxaca $(1973)^{3}$. This method decomposes the wage gap between gender groups into two components: one explained by observable differences in male and female characteristics ${ }^{4}$ and the other, residual, due to gender differences in the rates of return to those characteristics. This residual portion of the wage gap is generally interpreted as wage discrimination ${ }^{5}$. The basic idea of this procedure is that differences in wages between two groups can be partially explained by the fact that these groups have different attributes, whereas the remaining portion of the gap is potentially explained by wage discrimination.

Since its formulation, the Oaxaca (1973) method has played an important role in decomposing wage differentials by source. Numerous studies apply this conventional approach (e.g., Ashraf and Ashraf, 1993; Bertrand and Hallock, 2001; Kunze, 2005; Monk-Turner and Turner, 2001; Neuman and Weisberg, 1998; Plasman and Sissoko, 2004; Ward, 2001). For Portugal, studies aimed at analyzing the size and composition of the gap rely on the Oaxaca (1973) technique in their empirical analysis. Kiker and Santos (1991), based on micro data of the year 1985, conclude that $33 \%$ of Portuguese wage disparities is explained by gender differences in male and female characteristics, while the remaining $67 \%$ is attributed to differences in the rates of return to those characteristics (discrimination component). Vieira and Pereira (1993), who investigate wage differentials in the Azores islands for the year 1989, conclude that the wage gap stems primarily from differences in the rates of return to male and female characteristics. More recently, Santos and González (2003) and Vieira et al. (2005), relying on micro data for the periods 1985-1997 and 1985-1999, respectively, report results that indicate that the majority of the Portuguese wage gap is unexplained by gender differences in labor market attributes and is due to the effects of wage discrimination.

An alternative decomposition method aimed at the decomposition of gender wage differentials is provided by Brown et al. (1980). This method extends the traditional Oaxaca (1973) decomposition, incorporating the distinction between within occupation (intra-occupational) and across occupation (inter-occupational) wage differentials. The main idea is to measure how much of the overall gender wage gap is due to differences in male and female wages within occupations and how much is explained by gender differences in occupational distribution (occupational gender segregation). This distinction is important as it may shed light on whether policies aimed at reducing the gender wage gap should focus more upon promoting equality in pay within occupations or on the redistribution of labor across occupations (Kidd, 1993).

The Brown et al. (1980) wage decomposition equation may be derived as follows. Wage equations for male and female employees are expressed as:

$$
\ln w_{j}^{m}=\beta_{j}^{m} X_{j}^{m}+u_{j}^{m}
$$
tenure), although researchers often also include characteristics related to jobs, sectors, and firms. 5 Cotton (1988) considers that caution should be taken when interpreting the unexplained component of the gap as wage discrimination. The unexplained gap may also be due to unmeasured or unobserved labor market characteristics that differ between male and female employees. To be an exact measure of wage discrimination, all factors that determine wages must be accounted for. If for some reason (e.g., data set limitations) they are not, then the unexplained component will also reflect these omitted determinants, overstating the true effect of wage discrimination. 


\section{$3 0 \longdiv { 1 }$}

$\ln w_{j}^{f}=\beta_{j}^{f} X_{j}^{f}+u_{j}^{f}$

where the subscript $j$ indicates the occupation, the superscripts $m$ and $f$ indicate male and female gender, respectively, $\ln w_{j}^{m}$ and $\ln w_{j}^{f}$ are the natural logarithms of hourly wages, $\beta_{j}^{m}$ and $\beta_{j}^{f}$ are vectors of the coefficients to be estimated, $X_{j}^{m}$ and $X_{j}^{f}$ represent the matrices of the employees characteristics, and $u_{j}^{m}$ and $u_{j}^{f}$ are the error terms.

Given the proprieties of OLS estimation, it follows that:

$$
\begin{aligned}
& \ln \bar{w}_{j}^{m}=\hat{\beta}_{j}^{m} \bar{X}_{j}^{m} \\
& \ln \bar{w}_{j}^{f}=\hat{\beta}_{j}^{f} \bar{X}_{j}^{f}
\end{aligned}
$$

where $\ln \bar{w}_{j}^{m}$ and $\ln \bar{w}_{j}^{f}$ correspond to the average natural logarithms of hourly wages, $\hat{\beta}_{j}^{m}$ and $\hat{\beta}_{j}^{f}$ are vectors of the estimated regression coefficients, $\bar{X}_{j}^{m}$ and $\bar{X}_{j}^{f}$ and represent the matrices of the average values of the employees' characteristics. By denoting the proportion of employees in occupation $j$ by $P_{j}^{m}$ and $P_{j}^{f}$, where $j=1, \ldots \mathrm{J}$, it results that:

$$
\left(\ln \bar{w}^{m}-\ln \bar{w}^{f}\right)=\sum_{j=1}^{J} P_{j}^{m} \ln \bar{w}_{j}^{m}-\sum_{j=1}^{J} P_{j}^{f} \ln \bar{w}_{j}^{f}
$$

Adding and subtracting $\sum_{j=1}^{J} P_{j}^{f} \ln \bar{w}_{j}^{m}$ from the right hand side of equation (5) allows the decomposition of the overall wage gap to be written the following way:

$$
\left(\ln \bar{w}^{m}-\ln \bar{w}^{f}\right)=\sum_{j=1}^{J} P_{j}^{f}\left(\ln \bar{w}_{j}^{m}-\ln \bar{w}_{j}^{f}\right)+\sum_{j=1}^{J}\left(P_{j}^{m}-P_{j}^{f}\right) \ln \bar{w}_{j}^{m}
$$

The first term on the right hand side of equation (6) represents the intra-occupational component which measures the part of the gap that is due to differences in wages within occupations. The second term on the right hand side corresponds to the inter-occupational component. This portion of the wage differential is attributable to differences in the distribution of male and female employees across occupations. If within each occupation female employees were to earn the same wages as males, there would be no wage differential within occupations and thus the intra-occupational term would be equal to zero. On the other hand, if the portion of male and female employees were the same in each occupation, there would be no segregation. In this case, the inter-occupational term would be equal to zero (Kunze, 2000).

Both components may be decomposed into explained and unexplained components. In this case, the Brown et al. (1980) wage decomposition equation is written as:

$\left(\ln \bar{w}^{m}-\ln \bar{w}^{f}\right)=\sum_{j=1}^{J} P_{j}^{f} \hat{\beta}_{j}^{m}\left(\bar{X}_{j}^{m}-\bar{X}_{j}^{f}\right)+\sum_{j=1}^{J} P_{j}^{f} \bar{X}_{j}^{f}\left(\hat{\beta}_{j}^{m}-\hat{\beta}_{j}^{f}\right)+\sum_{j=1}^{J} \bar{X}_{j}^{m} \hat{\beta}_{j}^{m}\left(P_{j}^{m}-\hat{P}_{j}^{f}\right)+\sum_{j=1}^{J} \bar{X}_{j}^{m} \hat{\beta}_{j}^{m}\left(\hat{P}_{j}^{f}-P_{j}^{f}\right)$

The first two terms on the right hand side of equation (7) represent the intra-occupational component of the wage gap. The first term is the explained portion which captures the part of the within occupation differential that is due to the different levels of labor market characteristics. The 
second term is the unexplained portion, that is, the portion of the within wage differential that arises from gender differences in the rates of return to labor market characteristics and that is interpreted as wage discrimination.

The third and fourth terms on the right hand side of equation (7) correspond, respectively, to the explained and unexplained portions of the inter-occupational component. The parameter $\hat{P}_{j}^{f}$ represents the non-discriminatory occupational structure for female employees, that is, the vector of the predicted proportion of female employees who would be in occupation $j$ if females faced the same occupational structure as males ${ }^{6}$. The technique used for computing this non-discriminatory occupational structure is described in detail below.

The explained portion of the inter-occupational component measures the part of the across occupation wage differential that results from gender differences in labor market characteristics. Differences in occupational distribution are partially explained by differences in male and female endowments. The unexplained portion reflects the part of the across occupation wage differential that is not explained by differences in the two groups' characteristics and that is understood as employment discrimination. In this case, the wage differentials that result from differences in occupational distribution are attributable to discriminatory factors.

In summary, the explained portions of the intra-occupational and inter-occupational components correspond to wage differentials that result from differences in male and female labor market characteristics, whereas the unexplained portions of these components reflect wage disparities that cannot be accounted for on the basis of gender differences in those characteristics and that are interpreted as labor market discrimination ${ }^{7}$.

An important aspect of this decomposition procedure is the computation of the non-discriminatory occupational structure for women. This requires the estimation of a model of occupational attainment. Brown et al. (1980) specify a reduced form multinomial logit model of occupational attainment for male employees in order to capture how factors that influence occupational supply and demand decisions affect the probability of individual $i$ being employed in occupation $j^{8}$. This probability model may be defined as follows:

$$
P_{i j}=\operatorname{prob}\left(y_{i}=\text { occupation } j\right)=\frac{\exp \left(\beta_{j} x_{i}\right)}{\sum_{k=1}^{J} \exp \left(\beta_{k} x_{i}\right)} \quad i=1, \ldots N, \quad j=1, \ldots J
$$

where $N$ is the total number of observations, $J$ is the number of occupational categories, $\beta_{k}$ are vectors of the coefficients to be estimated, and $x_{i}$ represents exogenous variables that affect occupational supply and demand decisions.

In order to obtain the vector of predicted probabilities of being in each occupation for each female observation, the female characteristics are substituted into the estimated male

6 This procedure assumes that in the absence of discrimination, female employees would be distributed across occupations according to male allocation mechanism.

7 For the same reason appointed by Cotton (1988), Kidd and Shannon (1994) consider that caution should be taken when interpreting the unexplained portions as a measure of discrimination.

8 Brown et al. (1980) refer that the individual's employment in a certain occupation results from the interaction between labor demand factors and labor supply factors. Labor demand factors are related to the employer's willingness to hire the individual, which in turn depends on that individual's personal qualifications such as education, training, and experience. Labor supply factors are related to the individual's choice to work in a particular occupation. This choice may be derived from a utility function that includes at least three components: income of the occupation, taste for the work involved, and family size. 
multinomial equations. These predicted probabilities are then summed over observations to obtain the predicted female occupational distribution.

The general procedure to estimate the Brown et al. (1980) wage decomposition involves three main steps. First, the female predicted occupational distribution is calculated based on the estimation of a probability model of occupational attainment for male employees. Second, for each occupation and gender category, wage equations are estimated to obtain the values of $\hat{\beta}_{j}^{m}$ and $\hat{\beta}_{j}^{f}$. Finally, the information obtained in the two preceding steps is used to calculate the intra-occupational and inter-occupational components of equation (7), which are then summed to obtain the overall gender wage differential ${ }^{9}$.

The Brown et al. (1980) wage decomposition method is mainly applied to studies that focus on the role of occupational segregation in accounting for wage differentials between male and female employees. Estimates of within occupation and across occupation wage disparities are provided in studies of different countries, including the U.S. (Brown et al., 1980), Britain (Dolton and Kidd, 1994), Australia (Kidd, 1993), Canada (Kidd and Shannon, 1994), China (Meng and Miller, 1995), and Ireland (Reilly, 1991). The main findings of these studies indicate that most of the wage gap results from within occupation wage differentials rather from occupational segregation. For the Portuguese labor market, there is no known study that applies this decomposition procedure in an attempt to discern the contribution of intra-occupational and inter-occupational wage effects.

\section{The data}

The empirical analysis is first performed for the year 2004, based on micro data from the Quadros de Pessoal (Personnel Records). The Quadros de Pessoal is an extensive data set provided by the Portuguese Ministry of Labor and Social Solidarity. The data set is based on an annual employment survey that each firm in the Portuguese economy with paid personnel is legally obliged to fill in. Excluded from the legal obligation of answering the annual survey are both public administration ${ }^{10}$ and employers of domestic related services. For the remaining cases, firms are legally required to answer the employment survey in November of every year, based on information regarding the reference month of October.

The micro data gathered in the Quadros de Pessoal cover information at three different levels: the firm level, the establishment level, and the worker level. At the firm level, there is information on each firm's location, legal setting, capital stock, establishments, employment, economic activity, year of constitution, and sales volume. At the establishment level, the data cover information on the location, employment, and economic activity of each one of the firm's establishments.

Reported data at the worker level include information on each worker's gender, nationality, occupation, professional situation, qualifications, schooling, age, monthly wages, hours worked, and employment duration regime. Among the unique and remarkable characteristics of this data set are the richness and comprehensiveness of the information at the firm, establishment, and worker levels and the longitudinal linked employer-employee dimension of the data.

9 Various authors (Dolton and Kidd, 1994; Kidd and Shannon, 1994; Miller, 1987) consider that the Brown et al. (1980) decomposition method avoids the problem relative to Oaxaca's (1973) treatment of occupational distribution. Following the traditional Oaxaca approach, gender differences in occupational distribution are included in the wage decomposition by incorporating a sequence of occupational dummies in the matrices of male and female characteristics. Occupational distribution is considered exogenous and its inclusion is likely to increase the explained component of the wage gap and, therefore, diminish the unexplained component. However, if the male and female difference in occupational distribution is itself a result of discriminatory factors, then the traditional approach of considering the distribution as exogenously given may be misleading. 10 Public administration is excluded from the legal obligation of answering the employment survey except in cases of individual employment contracts. 
The observations included in the analysis correspond to 1,886,943 non-self employed full-time wage earners. Several constraints were imposed on the total number of observations of the original data set. In relation to the worker's professional status, only wage earners were included in the analysis. Firm owners, unpaid family members, and active members of cooperatives were, therefore, dropped. Employers engaged in the firm's activities and members of cooperatives were not considered since the distinction between wages and profits may not be sufficiently clear and non-subjective. Given that wage inequality is the main theme of this thesis, unpaid family members were also dropped from the original data set. Furthermore, only full-time wage earners, aged 16 to 64 , were retained for the analysis undertaken. Due to their low representation in the data set Quadros de Pessoal, observations related to the economic sectors of agriculture, forestry, fishery, mining, public administration, domestic service, and extra-territorial organizations were not included in the analysis. These economic sectors are not adequately covered by the annual survey since either they correspond to economic sectors explicitly excluded from the legal obligation to answer the annual survey, or they correspond to economic sectors that have a very low share of workers in total employment. From a geographical point of view, the empirical study is focused on the Portuguese mainland, therefore excluding observations regarding the autonomous regions of Azores and Madeira. Finally, and given the problems that the existence of missing values in the data set can bring to the computations to be performed, observations with missing data were also dropped from the original data set.

Table 1 provides descriptive statistics of both male and female employees ${ }^{11}$. For the year in analysis, female employees represent approximately $42 \%$ of the total labor force. The comparison of male and female average gross hourly regular wages reveals that women earn about $78 \%$ of men. Differences in the educational attainments of male and female employees are small: the average number of years of schooling is 8 for men and 9 for women. On average, male employees are older than their female counterparts and have more work experience prior to their current job. Job tenure is also slightly greater for men than for women.

\begin{tabular}{|c|c|c|c|c|c|c|}
\hline \multirow{2}{*}{ Characteristics } & \multicolumn{3}{|c|}{ Males } & \multicolumn{3}{|c|}{ Females } \\
\hline & $\%$ & Mean & St. & $\%$ & Mean & St. \\
\hline Share of employees by gender & 57.91 & & & 42.09 & & \\
\hline Ln hourly wage & & 1.54 & 0.59 & & 1.34 & 0.53 \\
\hline Education (years) & & 8.02 & 3.88 & & 8.76 & 4.05 \\
\hline$\leq 4$ & 27.91 & & & 23.19 & & \\
\hline 6 & 22.90 & & & 20.30 & & \\
\hline 9 & 21.79 & & & 20.32 & & \\
\hline 12 & 17.94 & & & 23.06 & & \\
\hline$\geq 15$ & 9.46 & & & 13.13 & & \\
\hline Age (years) & & 37.87 & 11.04 & & 36.39 & 10.34 \\
\hline Previous experience (years) & & 16.33 & 11.21 & & 14.77 & 11.08 \\
\hline Tenure (years) & & 7.52 & 8.57 & & 6.88 & 7.81 \\
\hline Ln firm size & & 3.83 & 2.29 & & 3.74 & 2.30 \\
\hline
\end{tabular}


Table 1 - Descriptive statistics for male and female employees, 2004 (cont.)

Characteristics

Males

Females

\begin{tabular}{l|l|l|l|l|l}
$\%$ & Mean & St. & $\%$ & Mean & St.
\end{tabular}

Region

\begin{tabular}{|c|c|c|}
\hline North Coast & 28.79 & 29.24 \\
\hline Center Coast & 15.01 & 14.65 \\
\hline Lisbon and Tagus Valley & 44.28 & 43.71 \\
\hline Inland & 8.44 & 8.33 \\
\hline Algarve & 3.48 & 4.07 \\
\hline \multicolumn{3}{|l|}{ Occupation } \\
\hline $\begin{array}{l}\text { Executive civil servants, industrial directors, } \\
\text { and executives }\end{array}$ & 5.19 & 2.72 \\
\hline Professionals and scientists & 4.81 & 5.67 \\
\hline Middle management and technicians & 12.73 & 9.66 \\
\hline Administrative and related workers & 11.47 & 23.81 \\
\hline Service and sales workers & 9.47 & 26.03 \\
\hline Skilled workers, craftsmen, and similar & 29.44 & 14.19 \\
\hline Machine operators and assembly workers & 16.23 & 5.33 \\
\hline Unskilled workers & 10.66 & 12.59 \\
\hline \multicolumn{3}{|l|}{ Industry } \\
\hline Food, beverages, and tobacco & 3.41 & 3.72 \\
\hline Textiles, clothing, and footwear & 4.61 & 13.42 \\
\hline Wood and cork & 1.86 & 0.87 \\
\hline Paper, printing, and publishing & 2.05 & 1.44 \\
\hline Chemical industries & 2.31 & 1.52 \\
\hline Non-metal mineral products & 2.70 & 1.45 \\
\hline Metal industries & 4.33 & 1.21 \\
\hline Other manufacturing industries & 2.15 & 1.34 \\
\hline Machinery and equipment & 5.47 & 3.24 \\
\hline Electricity, gas, and water & 0.79 & 0.22 \\
\hline Construction & 18.26 & 2.37 \\
\hline Trade & 20.84 & 21.72 \\
\hline Restaurants and hotels & 4.69 & 9.95 \\
\hline Transportation and communication & 8.96 & 3.52 \\
\hline Banking, insurance, and business services & 13.25 & 13.99 \\
\hline Social and personal services & 4.32 & 20.02 \\
\hline
\end{tabular}

Source: Computations based on Portugal, Ministério do Trabalho e da Solidariedade Social (2006).

Notes: The employee's hourly wage is defined as the total gross hourly amounts received on a regular basis and was computed as

$(b w+r s) / n h: b w$ is the base wage, $r s$ are regular subsidies, and $n h$ is the number of normal hours worked. The variable previous experience corresponds to the employee's working experience prior to the current job and was computed as (age-schooling-6-tenure). 
Although both groups of employees are similarly characterized in relation to the firm's size and location, they are distributed differently across occupations. While a substantial portion of male workers (58\%) are employed as production workers, machine operators, assembly workers, middle managers, and technicians, half of the female group is concentrated in administrative, service, and sales occupations. The two groups are also distributed differently across economic sectors. The three leading sectors are "trade", "construction", and "banking, insurance, and business services" for males and "trade", "social and personal services", and "banking, insurance, and business services" for females.

\section{Results of the Brown et al. (1980) decomposition method}

To calculate the Brown et al. (1980) wage decomposition, two intermediate steps are followed. The first step is to obtain the predicted female occupational structure if women were to be distributed across occupations according to the male allocation mechanism. This requires the estimation of a reduced form multinomial logit model of occupational attainment for the male sample ${ }^{12}$. The dependent variable is the probability of being in each of eight major occupational groups defined by the Portuguese Classification of Occupations ${ }^{13}$. The independent variables include years of previous work experience, as well as variable dummies for educational attainment and firm location ${ }^{14}$. The majority of the regression coefficients are statistically significant at the 0.01 level.

The simulated occupational distribution of female employees is obtained by substituting the female vector of characteristics into the estimated male equations. Table 2 displays the actual and predicted occupational distribution of female employees.

\section{Table 2 - Occupational distribution of female employees (\%), 2004}

\begin{tabular}{|l|l|l} 
Occupation & Actual (\%) & Predicted (\%)
\end{tabular}

Executive civil servants, industrial directors, and executives
2.72
5.69

\begin{tabular}{lcc}
\hline Professionals and scientists & 5.67 & 6.48 \\
\hline Middle management and technicians & 9.66 & 14.54 \\
\hline Administrative and related workers & 23.81 & 12.54 \\
\hline Service and sales workers & 26.03 & 9.43 \\
\hline Skilled workers, craftsmen, and similar & 14.19 & 26.75 \\
\hline Machine operators and assembly workers & 5.33 & 14.79 \\
\hline Unskilled workers & 12.59 & 9.78 \\
\hline
\end{tabular}

Source: Computations based on Portugal, Ministério do Trabalho e da Solidariedade Social (2006).

12 In order to save space, the multinomial logit estimates for male employees are not reported. The results are available upon request.

13 The computational problems that arise from estimating the multinomial logit model with a large set of occupations justify the use of a broad classification of occupations.

14 The variable relative to firm location is used as a proxy for the employee's residential location. 
According to the results, if female employees were to be allocated into occupations on the same basis as their male colleagues, given their characteristics, the female proportions of "executive civil servants, industrial directors, and executives", "professionals and scientists", "middle management and technicians", "skilled workers, craftsmen, and similar", and "machine operators and assembly workers" would increase, and the share of female employees in all other occupational groups would fall. Among the changes, the increase in female production workers, machine operators, and assembly workers would be the sharpest (an increase from 20 to $42 \%$ ), whereas the decrease in the proportion of women in administrative, service, and sales positions would be the most dramatic (a decrease from 50 to $22 \%$ ).

The second step followed to obtain the Brown et al. (1980) decomposition is the estimation of wage equations for each occupation and gender category ${ }^{15}$. According to the results, most of the coefficients have statistical significance at the 0.01 level.

The estimated components of the Brown et al. (1980) wage decomposition equation (equation 7) are summarized in Table 3 . The results indicate that the intra-occupational component dominates the explanation of the wage gap. Of the total gap, 0.191 (94\%) represents wage differentials within occupations, while $0.013(6 \%)$ corresponds to wage differentials that result from gender differences in occupational distribution (occupational gender segregation). Hence, the results show that the vast majority of the total gender wage gap is due to differences in male and female wages within the same occupations, whereas a small portion of the gap is explained by the fact that men and women are distributed differently across occupations.

\section{Table 3 - Brown et al. (1980) decomposition results, 2004}

\begin{tabular}{l|c|c|c|c|c|c}
\hline \multirow{2}{*}{$\begin{array}{l}\text { Total wage gap } \\
\left(\ln \bar{w}^{m}-\ln \bar{w}^{f}\right)\end{array}$} & \multicolumn{3}{|c|}{$\begin{array}{c}\text { Intra-occupational } \\
\text { Component }\end{array}$} & \multicolumn{3}{c}{$\begin{array}{c}\text { Inter-occupational } \\
\text { Component }\end{array}$} \\
\cline { 2 - 8 } & Total & Explained & Residual & Total & Explained & Residual \\
\hline 0.204 & 0.191 & 0.037 & 0.154 & 0.013 & -0.037 & 0.050 \\
\hline
\end{tabular}

Source: Computations based on Portugal, Ministério do Trabalho e da Solidariedade Social (2006).

The breakdown of the intra-occupational component into explained and unexplained portions reveals the relative importance of the latter in explaining within occupation wage differentials. While approximately $19 \%$ of the intra-occupational component is due to differences in male and female labor market characteristics, $81 \%$ cannot be explained by those differences. Hence, the estimated results indicate that for the year in analysis a significant portion of the intra-occupational gender wage gap in Portugal is unexplained by gender differences in endowments and is due to wage discrimination. These results are consistent with previous research on the overall Portuguese gender wage gap. Relying on the Oaxaca (1973) technique, several studies aimed at analyzing the size and composition of the Portuguese wage gap (e.g., Kiker and Santos, 1991; Santos and González, 2003; Vieira et al., 2005; Vieira and Pereira, 1993) report results that indicate that the majority of the gap is unexplained by gender differences in labor market attributes and is due to the effects of gender wage discrimination.

As for the inter-occupational component, the explained portion is negative $(-0.037)$, implying that gender differences in labor market characteristics favor female employees in relation to wage disparities that arise from the two groups' occupational distributions. The results further reveal that this portion is totally offset by the unexplained portion. 
In sum, the estimated results of the Brown et al. (1980) wage decomposition show that in the year 2004 the Portuguese gender wage gap is mainly explained by wage disparities within occupations and that occupational gender segregation is not a major contributor to the observed gap. The results also reveal that when combining the within occupation and across occupation wage effects, the total!unexplained portion accounts for the entire gap ${ }^{16}$.

The final step of the present analysis is to extend the wage decomposition performed for the year 2004 to the period 1986-2003 ${ }^{17}$. The estimates of the Brown et al. (1980) wage decomposition are summarized in Table $4^{18}$

\begin{tabular}{c|c|c|c|c|c|c|c}
\hline \multicolumn{2}{c}{ Table 4 - Brown et al. (1980) decomposition results, 1986-2004 } \\
\hline Year & $\begin{array}{c}\text { Total wage gap } \\
\left(\ln \bar{w}^{m}-\ln \bar{w}^{f}\right)\end{array}$ & \multicolumn{3}{|c|}{$\begin{array}{c}\text { Intra-occupational } \\
\text { Component }\end{array}$} & \multicolumn{3}{c}{$\begin{array}{c}\text { Inter-occupational } \\
\text { Component }\end{array}$} \\
\cline { 3 - 8 } & Total & Explained & Residual & Total & Explained & Residual \\
\hline 1986 & 0.244 & 0.230 & 0.096 & 0.134 & 0.014 & -0.008 & 0.022 \\
\hline 1992 & 0.283 & 0.265 & 0.101 & 0.164 & 0.018 & -0.010 & 0.028 \\
\hline 1998 & 0.256 & 0.217 & 0.055 & 0.162 & 0.039 & -0.018 & 0.057 \\
\hline 2004 & 0.204 & 0.191 & 0.037 & 0.154 & 0.013 & -0.037 & 0.050 \\
\hline
\end{tabular}

Source: Computations based on Portugal, Ministério do Trabalho e da Solidariedade Social (2006).

Notes: Nominal wages were deflated using the Consumer Price Index gathered by the Portuguese Statistical Office (Portugal, Instituto Nacional de Estatística, 2006). The computations were performed considering the year 2004 as the base period.

The estimates reveal that over time gender differences in occupational distribution have had a rather insignificant role in determining gender wage disparities. Hence, according to this wage decomposition methodology, the role of within occupation wage disparities in determining the overall wage gap has been prominent over time.

The results displayed in Table 4 further reveal that in the period under analysis the majority of the within occupational wage disparities are not explained by gender differences in observed labor market characteristics. The explained portion accounts for $42 \%$ of the intra-occupational gap in 1986 and $19 \%$ in 2004 , whereas the unexplained portion varies from $58 \%$ in 1986 to $81 \%$ in 2004.

The estimates also show that the explained portion of the across occupation component is negative in all years, indicating that over time gender differences in measured endowments have favored female employees in relation to wage disparities that stem from occupational segregation. The explained portion is, however, completely offset by the unexplained portion in all years.

16 As explained earlier on, the Brown et al. (1980) method interprets the unexplained portions of the intra-occupational and inter-occupational components as labor market discrimination. However, it is possible that not all of the determinants of wages are measured or observed using the available data set. Therefore, the unexplained portions of the gap may also reflect omitted labor market characteristics that differ between males and females.

17 The empirical analysis is performed based on micro data for four years: 1986, 1992, 1998, and 2004. The fact that these four years span over two decades in sub-periods of equal length allows for the detection and explanation of wage inequality patterns.

18 In order to save space, the descriptive statistics of male and female employees over the period 1986-2003 are not reported. The results are available upon request. 
Furthermore, the Brown et al. (1980) decomposition results indicate that in the time period under study the explained portions of both the within and the across occupation components fell, whereas the unexplained portions of both components rose ${ }^{19}$. Hence, the results suggest that the narrowing of the overall gender wage gap is attributable to the decrease in the portions of the gap due to gender differences in the levels of measured human capital characteristics.

\section{Conclusion}

The purpose of this paper was to study the role of occupational segregation in explaining wage disparities between male and female workers in the Portuguese economy. The main objective was to investigate to what extent gender wage disparities can be explained by differences in the occupational distribution of male and female employees.

The Brown et al. (1980) wage decomposition method was applied to micro data from the Quadros de Pessoal, over a nineteen year period (1986-2004). The estimates reveal that over the years the portion of the gap explained by wage disparities within the same occupation has been considerably greater than the portion that has stemmed from differences in the occupational distribution of male and female employees. These results therefore provide evidence that occupational gender segregation has not been a major contributor to the wage gap and that intra-occupational wage effects have played a prominent role in determining the overall differential. Hence, labor market policies aimed at reducing the gender wage gap in the Portuguese economy might be more effective if directed more at promoting equal pay within occupations rather than at attempting a more equal distribution of male and female employees across occupations. The estimates also indicate that a large portion of the male-female wage gap has been unexplained by gender differences in measured labor market characteristics and has been attributable to wage discrimination against female employees or to differences in the levels of unobserved male and female endowments. These results are consistent with previous research on the overall Portuguese gender wage gap. This research, relying on the Oaxaca (1973) decomposition method, indicates that the majority of the wage gap is not explained by gender differences in labor market characteristics and that a substantial portion of the gender gap is explained by wage discrimination against female employees.

Additionally, the empirical evidence reveals that over the period 1986-2004 the portion of the gap explained by gender differences in measured endowments decreased, contributing to the narrowing of the overall Portuguese gender wage gap. As for the unexplained component, the results indicate that this part of the wage gap increased, potentially due to a rise in labor market discrimination or to an increase in gender differences in unmeasured labor market characteristics.

It is important to note several limitations of the empirical analysis undertaken in this paper. First, the conclusions drawn in this study are based upon an analysis performed for a broad set of occupational groups. It is possible that the decomposition approach may be sensitive to the level of occupational aggregation. The narrower the definition of occupation, the larger the possibility of the total wage differential that may be attributed to inter-occupational effects. Second, the analysis is constrained with regard to the data collected in the survey. Hence, the specification regarding the occupational attainment model may be subject to variable bias. The study of the issue raised in this paper using more detailed information on occupational attainment is desirable. In view of these limitations, the results in this paper should be interpreted as suggestive rather than as definitive. 


\section{References}

Aigner, Dennis J.; Cain, Glen G. (1977) Statistical Theories of Discrimination in Labor Markets, Industrial and Labor Relations Review, 30, 2, 175-187.

Ashraf, Javed; Ashraf, Birjees (1993) Estimating the Gender Wage Gap in Rawalpindi City, Journal of Development Studies, 29, 2, 365-376.

Becker, Gary S. (1957) The Economics of Discrimination, Chicago, University of Chicago Press.

Bertrand, Marianne; Hallock, Kevin F. (2001) The Gender Gap in Top Corporate Jobs, Industrial and Labor Relations Review, 55, 1, 3-21.

Blau, Francine D.; Ferber, Marianne (1986) The Economics of Women, Men, and Work, New Jersey, Prentice-Hall.

Blau, Francine D.; Kahn, Lawrence M. (1996) Wage Structure and Gender Earnings Differentials: an International Comparison, Economica, 63, 250, 29-62.

Blau, Francine D.; Kahn, Lawrence M. (1999) Analyzing the Gender Pay Gap, Quarterly Review of Economics and Finance, 39, 5, 625-646.

Blinder, Alan S. (1973) Wage Discrimination: Reduced Form and Structural Estimates, Journal of Human Resources, 8, 4, 436-455.

Boraas, Stephanie; Rodgers, William M. (2003) How Does Gender Play a Role in the Earnings Gap?, Monthly Labor Review, 126, 3, 9-15.

Brown, Randall S. et al. (1980) Incorporating Occupational Attainment in Studies of Male-Female Earnings Differentials, Journal of Human Resources, 15, 1, 3-28.

Cardoso, Ana Rute (1996) Women at Work and Economic Development: Who's Pushing What?, Review of Radical Political Economics, 28, 3, 1-34.

Cotton, Jeremiah (1988) On the Decomposition of Wage Differentials, Review of Economics and Statistics, 70, 2, 236-243.

Dex, S.; Sloane, P. J. (1988) Detecting and Removing Discrimination under Equal Opportunities Policies, Journal of Economic Surveys, 2, 1, 1-27.

Dolton, Peter J.; Kidd, Michael P. (1994) Occupational Access and Wage Discrimination, Oxford Bulletin of Economics and Statistics, 56, 4, 457-474.

Kidd, Michael P. (1993) Sex Discrimination and Occupational Segregation in the Australian Labour Market, Economic Record, 69, 204, 44-55.

Kidd, Michael P.; Shannon, Michael (1994) An Update and Extension of the Canadian Evidence on Gender Wage Differentials, Canadian Journal of Economics, 27, 4, 918-938.

Kiker, B. F.; Santos, Maria C. (1991) Human Capital and Earnings in Portugal, Economics of Education Review, 10, 3, 187-203.

Kunze, Astrid (2000) The Determination of Wages and the Gender Wage Gap: a Survey, Institute for the Study of Labor Discussion Paper 193.

Kunze, Astrid (2005) The Evolution of the Gender Wage Gap, Labour Economics, 12, 1, 73-97.

Meng, Xin; Miller, Paul (1995) Occupational Segregation and Its Impact on Gender Wage Discrimination in China's Rural Industrial Sector, Oxford Economic Papers, 47, 1, 136-155.

Miller, Paul W. (1987) The Wage Effect of the Occupational Segregation of Women in Britain, Economic Journal, 97, 388, 885-896.

Mincer, Jacob; Polachek, Solomon (1974) Family Investments in Human Capital: Earnings of Women, Journal of Political Economy, 82, 2, 76-108. 
Monk-Turner, Elizabeth; Turner, Charlie G. (2001) Sex Differentials in Earnings in the South Korean Labor Market, Feminist Economics, 7, 1, 63-78.

Neuman, Shoshana; Weisberg, Jacob (1998) Gender Wage Differentials and Discrimination among Israeli Managers, International Journal of Manpower, 19, 3, 161-170.

Oaxaca, Ronald (1973) Male-Female Wage Differentials in Urban Labor Markets, International Economic Review, 14, 3, 693-709.

Plasman, Robert; Sissoko, Salimata (2004) Comparing Apples with Oranges: Revisiting the Gender Wage Gap in an International Perspective, Institute for the Study of Labor Discussion Paper 1449.

Portugal, Instituto Nacional de Estatística (1973) Classificação Portuguesa das Actividades Económicas, Lisboa, Instituto Nacional de Estatística.

Portugal, Instituto Nacional de Estatística (2003) Classificação Portuguesa das Actividades Económicas (CAE - REV. 2.1), Lisboa, Instituto Nacional de Estatística.

Portugal, Instituto Nacional de Estatística (2006), Índices de Preços no Consumidor, Lisboa, Instituto Nacional de Estatística.

Portugal, Ministério do Emprego e da Segurança Social (1994) Classificação Nacional das Profissões. Versão 1994, Lisboa, Instituto do Emprego e Formação Profissional.

Portugal, Ministério do Emprego e da Segurança Social (1998) Classificação Nacional das Profissões. Versão 1994. Adenda, Lisboa, Instituto do Emprego e Formação Profissional.

Portugal, Ministério do Trabalho e da Solidariedade Social (2006) Quadros de Pessoal, Data in magnetic media.

Preston, Jo Anne (1999) Occupational Gender Segregation: Trends and Explanations, Quarterly Review of Economics and Finance, 39, 5, 611-624.

Reilly, Barry (1991) Occupational Segregation and Selectivity Bias in Occupational Wage Equations: an Empirical Analysis Using Irish Data, Applied Economics, 23, 1, 1-7.

Santos, Maria Clementina; González, Maria do Pilar (2003) Gender Wage Differentials in the Portuguese Labor Market, Research Center on Industrial, Labour, and Managerial Economics Discussion Paper 3.

Stenzel, Tamara F. (2001) Why Is There a Gender Wage Gap and How Can We Fix It?, Employee Rights Quarterly, 2, 2, 1-7.

Terrell, Katherine (1992) Female-Male Earnings Differentials and Occupational Structure, International Labour Review, 131, 4, 387-404.

Vieira, José A. Cabral et al. (2005) Gender Segregation and the Wage Gap in Portugal: an Analysis at the Establishment Level, Journal of Economic Inequality, 3, 2, 145-168.

Vieira, José A. Cabral; Pereira, Pedro Telhado (1993) Wage Differential and Allocation: an Application to the Azores Islands, Economia, 17, 2, 127-159.

Ward, Melanie (2001) The Gender Salary Gap in British Academia, Applied Economics, 33, 13, 1669-1681.

Wooldridge, Jeffrey M. (2001) Econometric Analysis of Cross Section and Panel Data, Cambridge, MIT Press. 